Keywords: Decision support systems Distributed decision making Routing Artificial intelligence Operation research

Historic:

Received 21/03/2017 Accept 02/08/2017

Palavras chave: Sistema de suporte à decisão Tomada de decisão distribuída Roteamento Inteligência artificial Pesquisa operacional

${ }^{+}$Correspondence: araujocaj@gmail.com
Carlos Alberto Araújo Júnior ${ }^{1+}$, Helio Garcia Leite², Carlos Pedro Boechat Soares ${ }^{2}$, Daniel Henrique Breda Binoti ${ }^{2}$, Amaury Paulo de Souza ${ }^{2}$, Antônio Ferraz Santana ${ }^{2}$, Carlos Moreira Miquelino Eleto Torre ${ }^{2}$

\section{A MULTI-AGENT SYSTEM FOR FOREST TRANSPORT ACTIVITY PLANNING}

ABSTRACT: This study aims to propose and implement a conceptual model of an intelligent system in a georeferenced environment to determine the design of forest transport fleets. For this, we used a multi-agent systems based tool, which is the subject of studies of distributed artificial intelligence. The proposed model considers the use of plantation mapping (stands) and forest roads, as well as information about the different vehicle transport capacities. The system was designed to adapt itself to changes that occur during the forest transport operation process, such as the modification of demanded volume or the inclusion of route restrictions used by the vehicles. For its development, we used the Java programming language associated with the LPSolve library for the optimization calculation, the JADE platform to develop agents, and the ArcGis Runtime to determine the optimal transport routes. Five agents were modelled: the transporter, controller, router, loader and unloader agents. The model is able to determine the amount of trucks among the different vehicles available that meet the demand and availability of routes, with a focus on minimizing the total costs of timber transport. The system can also rearrange itself after the transportation routes change during the process.

\section{SISTEMA MULTI-AgENTE PARA PLANEJAMENTO DE ATIVIDADES DE TRANSPORTE FLORESTAL}

RESUMO: O presente estudo objetivou propor e implementar um modelo conceitual de sistema inteligente em um ambiente georreferenciado para dimensionar a frota de transporte de madeira. Para isso, foi utilizada a teoria dos sistemas multiagentes, a qual é uma sub-área da Inteligência Artificial Distribuída. $O$ modelo proposto considera a utilização do mapeamento de talhões e estradas florestais, bem como de informações sobre as capacidades de carga de diferentes tipos de caminhões. $O$ sistema foi idealizado para se adaptar às mudanças que ocorrem durante a operação de transporte florestal, tal como modificações no volume de madeira demandado ou inclusão de restrições das rotas utilizadas pelos veículos. Para seu desenvolvimento, foi utilizada a linguagem de programação Java considerando-se a biblioteca LPSolve para os cálculos de otimização do sistema, a plataforma JADE para desenvolvimento dos agentes e a ArcGIS Runtime para determiner as rotas ótimas de transporte. Cinco agentes foram modelados: transportador, controlador, roteador, carregador e descarregador. O modelo foi capaz de determiner a quantidade ótima de caminhões dentre os diferentes tipos disponíveis de forma a attender a demanda de madeira e considerando a disponibilidade de rotas, com foco na minimização dos custos totais do transporte da madeira. $O$ sistema também foi capaz de se rearranjar após alterações nas rotas de transporte. 


\section{INTRODUCTION}

Transportation of timber is an activity that constitutes a large proportion of the production costs in forest enterprises. According to Frisk et al. (2010), approximately thirty percent of the costs of the total raw material in the forest industry are expenses related to the transportation of logs from stands to the processing units. The distance from the source of timber to the destination and the fact that trucks used for transportation often travel loaded in only one direction contribute to the high costs (MACHADO et al., 2009; RENTIZELAS et al., 2009).

Among the factors that affect the transportation costs, the travel distance is the most important one (SILVA et al., 2007), making some projects infeasible/ impractical or greatly decreasing their profits. Because of this, some forest managers define a maximum radius for the crop area around the mills, aiming to avoid the high costs of wood transportation. However, sometimes this is not possible because of land availability or increase in wood demand and it will require the coverage large distances to maintain the mill's supply.

In situations in which plantations are already stablished and the transportation costs need to be decreased, tools such as optimization, simulation and GISs can be applied to accomplish such task. Examples of works addressing this type of situation include the studies by Lopes et al. (2003) and Rix et al. (2014). The first authors used software called SNAP III to identify the harvest systems and the best routes to transport the wood in each period of the planning. The second one used mixed integer linear programming to solve a forest transportation problem considering two types of trucks, the schedule of the freight and the route selection. Other works are presented by Berger et al. (2003) and Troncoso and Garrido (2005). However, in most cases, the studies involved traditional planning with the use of operational research techniques, which aims at creating optimal plans that must be followed by the operational sectors of the enterprise.

The operationalization of wood transport planning is often hard, mainly because of the presence of aspects not considered in the mathematical models used. When the manager tries to considerer these aspects, the model becomes too complex, resulting in a combinatorial problem in whose resolution is difficult and incurring high computational costs, as suggested by Baskent (200I).

Aiming to avoid these drawbacks of classic operational research, computational tools have been used in forest transportation problems, such as the use of simulated annealing (HARIDASS et al., 20I4), ant colony optimization (LIN et al., 2016) and tabu search (FLISBERG et al., 2009). Simulation techniques also have been adopted, such as Petri Net (MACHADO et al., 2006) and system dynamics (JIFENG et al., 2008). However, these tools do not make use of the features provided by georeferenced environments. In addition, these solution tools are not dynamic, as they do not consider the possibility of real time monitoring. Indeed, Davidsson and Wernstedt (2002) mentioned that static approaches are limited when applied to dynamic phenomena, as is the problem of forest transportation operational planning. This demonstrates the importance of searching for new tools to apply to forest planning, especially that from the field of artificial intelligence (AI).

In this context, an area of $\mathrm{Al}$ that has been the subject of many recent works is distributed artificial intelligence (DAI). Using this technique, the problem is divided into parts (agents) capable of interacting with and searching individual solutions that provide the best solution to the problem (KONAR, 2000). The philosophic basis of DAl is social behaviour, meaning that the various agents act in a given environment, following rules to reach individual goals and interacting with each other to reach the global goal. DAI has been used in various works involving management and scheduling of production using the paradigm called multi-agent systems (MAS) (LEITÃO et al., 2012; DOMÍNGUEZ, 2013). The use of MAS has been increasingly common since 1990 because of the advances in computational systems and because each process in a supply chain can be modelled as an agent with its own decision rules.

The multi-agent system has also been used in logistic process management and vehicle routing problems. Kohout and Erol (1999) worked with an agent based model to solve the vehicle routing problem involving the transportation of passengers at an airport. In that work, the multi-agent approach was able to treat the problem in a dynamic way, with real-time solutions, allowing for parameter variations in the model to be considered at each moment. This demonstrates that multi-agent systems also offer an answer to the limitations of traditional approaches in operations research, representing complex and dynamics problems that are hard to express using mathematical formulas (DONIEC et al., 2008), which, in most cases, use static variables (KOHOUT; EROL, 1999).

Many studies have already been performed using MASs for transportation planning and management problems (CHEN; CHENG, 20I0). Moreover, there are 
many publications about the use of MASs for modelling, analysis and solutions of product transportation problems. This shows that there is an opportunity to build a model using the multi-agent system paradigm for the wood transportation problem in forest enterprises. However, no work has been done considering this approach for the planning and management of wood supply chains. Thus, this work proposes the development of a multiagent system for the planning of forest transportation. This model will consider the dimensioning of the truck fleet and the possibility to treat interruptions during the operation to simulate real-time conditions.

\section{MATERIAL AND METHODS}

\section{Conceptual model and correspondent agents}

To model a system based on multi-agent theory, there needs to be a real-world abstraction. Therefore, considering a forest transportation problem, the system was made to represent the elements associated to the environment (stands, roads and yard) and the elements that can be represented by agents (trucks, wood loader and unloader machines, a person or sector responsible by the truck routing and a person or sector responsible by planning the operations).

A - Stands, roads and yard (environment)

The stands are polygons in any forest area. They have an available wood volume to be transported and are considered to be the source of the wood to the yard or mill. The available wood volume in each stand depends upon the characteristics of the stand. They are connected to each other and to the yard by a road network, where each track of the road could be inactivated by events that may interrupt the traffic at any period. These events could cause problems in the execution of the transportation plan. All these elements were considered as components of the georeferenced environment in the multi-agent model, allowing the system to estimate the distance between the stands and yard and compute the best route to transport the wood.

B- Trucks

The forest transportation activity could be done with different types of vehicles, which vary in their load capacity and other characteristics, such as costs and speed of traffic (RENTIZELAS et al., 2009). Therefore, each type of truck has its own size, efficiency and operational costs, which must be analysed before choosing the best blend of trucks in a fleet for wood transport.

In the multi-agent system, it was necessary create a truck agent (TA) responsible for the transport of wood. It was parametrized with information about load capacity, type of vehicle, costs, speed when empty and speed when loaded. When initialized, the truck agent must evaluate the transport plan to know what stand will be source of wood for transport activity. It will communicate with the router agent to request the best route between the yard and stand. When it arrives at the stand, it needs to communicate with the loading agent and request a volume of wood to be transported. After being loaded, the truck agent requests a new route from the router agent and the expected time to move from the stand to the yard. This is necessary because problems can occur in a track during the time that the truck is occupied with the loading operation. When the truck agent arrives at the yard, it communicates with the unloader agent, informing the agent of the amount of wood available to be stocked, at which point the unloader agent can start its function.

\section{C- Wood loader machine}

The load machines are in the stands and have their own operational capabilities. These machines can move to other forest compartments when the volume is null in the current stand.

Agents that represent the wood loaders are responsible for managing the stocks of wood in the forest and can move in the environment from one stand to another when the first has finished its volume. The initial behaviour of this agent is to wait for the truck agent to request the loading operation. The truck loading activity only occurs if there is volume at the current stand. When this communication happens, the agent reacts according to a communication protocol. Thereby, the loader agent (LA) must be parametrized with the time of the load per unit volume $\left(\mathrm{min} \mathrm{m}^{-3}\right)$ to estimate the time it will take to load each truck. When the load operation finishes, the loader agent sends a message to the truck agent, allowing it to transport the wood from the yard. If there is more than one truck waiting for load, the loader machine creates a queue of waiting.

D- Wood unloader machine

Similar to the load machines, the wood unloader has its own operational capabilities that must be considered in multi-agent modelling. In the case of the unload machines, they must be located at the yard, without permission to move to another site, and their function is only to unload the trucks and put the wood in an appropriate local yard.

The agents that represent the wood unloader do not move around the environment and its position is limited to the yard, since this work does not require 
movement from one yard to another. Its function is only to receive wood from the trucks and store it in an appropriate location. For this, the unloader agent (UA) awaits the message from the truck agent requesting the unload operation. Considering the volume of wood available in the truck and the parametrized time to unload per unit volume $\left(\mathrm{min} . \mathrm{m}^{-3}\right)$, the unload agent estimates the time necessary to finish the operation. In this time interval, it performs this current activity and puts other requests in a list that will be examined after the operation. After finishing the unload operation, the unloader agent sends a message to the truck, allowing it to acquire new freight. If there is more than one truck waiting for unload, the unloader machine creates a queue of waiting.

\section{E- Router}

The knowledge about distances and the shortest path between the stands and yard is necessary in forest transportation systems and is used to create a transport schedule that minimizes the total distance travelled (HARIDASS et al., 20I4). Therefore, route optimization is necessary not only when the manager is planning the operation but also when there is an interruption in any part of the track and an alternative path is needed. This consideration is especially significant when strong rains occur, bridges crack, and forest fire occur since they can cause temporary or permanent interruption to the initial route.

Thus, it is important for the model to include an agent that monitors these events and is responsible for indicating the best route between the stands and yard. This component was called the router agent (RA). It determines the best track using a traditional algorithm, Dijkstra's algorithm. Initially, this agent measures the best distance between each stand and the yard and sends this information to the planner agent. Next, the agent waits for messages from the truck agents requesting routes. When these messages arrive, the router agent estimates the best route and sends a message to the truck agent updating the route, distance and time estimation of the trip. When any event occurs in the environment, the router agent recalculates each distance from the stands to the yard and sends this information to the planner agent, allowing it to recalculate the amount of trucks that should be used in the forest transportation. In this case, the exceeding trucks are inactivated after deliver its wood at yard. This will ensure that the system can replan its operations during the processing period.

F- Planner

Every enterprise needs a person or set of persons that creates a plan for the rest of the operation area. In forest transportation problems, it is necessary to define a plan that considers the amount of wood to be delivered at yard in a period of time, aiming to maintain a constant flow of wood from the forest. For that, information is needed about the truck types available, their characteristics and the distance between stands and the yard. With that, the planner can create a mathematical model to solve the problem in an optimal way. Therefore, it is necessary for an agent to execute this process, with focus on minimizing cost. In this multiagent system, this agent is called the planner agent (PA) and is responsible for determining the amount of trucks necessary for the wood transport. To do so, it evaluates the environmental conditions, the routes calculated by the router agent and the characteristics of the available truck and then estimates the best composition of trucks that can deliver the amount of wood requested by the yard. For this, the PA solves the integer linear problem given as, where $C_{j}$ is the coefficient that represents the average cost of transport activity for each $j$ truck $\left(R \$ \mathrm{~m}^{-3}\right.$ $\left.\mathrm{km}^{-1}\right) ; V_{j}$ is the capacity transported by the truck, $j$, in an interval equal to one hour $\left(\mathrm{m}^{3}\right.$ hour $\left.{ }^{-1}\right) ; d_{t}$ is the average distance of transport considering all of the stands $(\mathrm{km})$; $X_{j}$ is the decision variable, representing the amount of trucks from type $j$ that will be used during transport operation; and $D$ is the amount of wood demanded from the mill in one hour $\left(\mathrm{m}^{3}\right.$ hour $\left.{ }^{-1}\right) ; V_{j}$ is calculated from the equation; $W_{j}$ is the wood capability for the vehicle type $j$ $\left(\mathrm{m}^{3}\right) ; N_{j}$ is the amount of times that the truck $j$ can carry timber in an hour; $s_{j}$ is the average speed for the vehicle type $j\left(\mathrm{~m}^{3}\right) ; t l_{j}$ is the time necessary to load truck type $j$ and $t u_{j}$ is the time necessary to unload truck type $j$.

$\min z=\sum_{j=1}^{n}\left(C_{j} V_{j} d_{t}\right) X_{j}$

s.t. $\sum_{j=1}^{n} v_{j} x_{j} \geq D$

$\mathrm{X}_{\mathrm{j}} \geq 0 \forall \mathrm{j}=[1, \mathrm{n}]$

$X_{j} \in Z+\forall j=[1, n]$

$\mathrm{V}_{\mathrm{j}}=\mathrm{N}_{\mathrm{j}} \mathrm{W}_{\mathrm{j}}$

$N_{j}=\left[\frac{2 d_{t}}{s_{j}}+W_{j}\left(\frac{t l_{j}+t u_{j}}{60}\right)\right]^{-1}$ 
Another behaviour of this agent is found when there is an interruption at any part or the road net. It calculates the best solution to the interruption problem, evaluating the costs associated with one of two possibilities: (I) transport of the wood from the current stand but using a sub-optimal route and (2) modification of the stand that supplies the wood to a stand that maintains the total average distance constant during the period of interruption.

Cost $\left(C_{l}\right)$ in the first alternative is calculated by the evaluation of amount of volume transported, considering the time of interruption and the distance of the suboptimal route, given as, where $c_{j}$ and $V_{j}$ are as defined before; $Q_{j}$ is the quantity of truck type $j$ that there are in the transportation fleet; $d_{i r}$ is the distance from stand $i$ to the yard; $v r_{i}$ is the volume that can be transported from stand $I$ to the yard during the interruption time, both considering the track restriction; $d_{i w r}$ is the distance from stand $i$ to the yard; $v w r_{i}$ is the volume that can be transported from stand $I$ to the yard during the interruption time, both considering a route without restrictions. Lastly, $n$ is the number of truck types and $m$ is the number of stands.

$C_{1}=\left(\sum_{j=1}^{n} C_{j} V_{j} Q_{j}\right)\left(\sum_{j=1}^{n} V_{j} Q_{j}\right)^{-1}\left(\sum_{i=1}^{m} d_{i r} v r_{i}-\sum_{i=1}^{m} d_{i} w r v w r_{i}\right)$

For cost $\left(C_{2}\right)$ calculated in the second alternative, the planner agent needs to identify the stands that will not supply their wood while the temporary restriction is active. Thereby, it solves a binary integer linear problem aiming to maximize the amount of wood transported without drastically changing the total average distance of transport. The mathematical model is 8,9 and 10 , where $V_{i}$ is the current volume of wood available at stand $i ; T_{i}$ is the binary decision variable that indicates if the stand $i$ will be transported $\left(T_{i}=1\right)$ or not transported $\left(T_{i}=0\right)$ during the interruption time; $d_{i r}$ is as defined before; $d_{a \text { wr }}$ is the total average distance of transport $(\mathrm{km})$ without considering the interruption and $m$ is the number of stands analysed.

$$
\begin{aligned}
& \max z=\sum_{j=1}^{n} V_{i} T_{i} \\
& \text { s.t. } \sum_{i=1}^{m}\left(d_{i r}-d_{a w r}\right) T_{i} \leq 0 \\
& X_{i} \in\{0,1\} \forall i=[1, m]
\end{aligned}
$$

The planner agent knows the stand that can receive the load agent will continue the operations with the report from the solver. In this case, it is necessary to estimate the cost involved with the change of the load location, which is composed of the costs of a vehicle to move the load machine from the current stand to the next stand. This cost is composed of variable and fixed costs. Thereby, the planner agent estimates the cost $C_{2}$ using the following formula, where $d_{y s}$ is the distance between the yard and the current stand, $d_{s s}$ is the distance between the current stand to the next stand, $d_{s y}$ is the distance between the next stand to yard; $C_{v}$ is a variable cost of operation $\left(\mathrm{R} \$ \cdot \mathrm{km}^{-1}\right)$ and $C_{f}$ is the fixed cost of operation ( $R \$$ ). The value 2 in expression II is in accordance with the fact that there are costs to move the load machine to the next stand and to move it to the previous stand when the interruption is finished.

$\mathrm{C}_{2}=2\left(\mathrm{~d}_{\mathrm{ys}}+\mathrm{d}_{\mathrm{ss}}+\mathrm{d}_{\mathrm{sy}}\right) \mathrm{C}_{\mathrm{v}}+\mathrm{C}_{\mathrm{f}}$

Figure I shows the multi-agent system environment and how the agents interact with $t$ with other agents to plan and replan the wood transport.

\section{System development}

The Java programming language was chosen to implement the proposed multi-agent system based on the conceptual model. The software was built with the Netbeans IDE (Integrated Development Environment) version 8.0.2 in Windows I0. A computer with an Intel Core i7 with $2.0 \mathrm{GHz}$ and RAM memory of $8 \mathrm{~GB}$ was used for programming and to testing.

JADE (Java Agent Development framework) was used for agent development and management. It is an "open source" platform for development of agent-based systems, and it was idealized in the 1990s (BELLIFEMINE, 2007) to consider the FIPA (Foundation for Intelligent Physical Agents) agent communication patterns (WOOLDRIDGE, 2002). The version used was the JADE v4.3.3 API (http://jade.tilab.com).

The LPSolve Java library was used to solve the optimization problems. It is a mixed linear programming solver that uses the Simplex and branch-and-bound algorithms. The library's version used was version 5.5 (http://lpsolve.sourceforge.net). We used the ArcGis Runtime SDK (Software Development Kit) for Java to embed the forest area mapping and the spatial analysis functions into the system, such as the geographic locations of the stands and yard, the definition of the best route from the stand to the yard, the presence of barriers in part of the road and the identification of these barriers inserted by the user. This API is available by ESRI in its page for software developers (https://developers.arcgis.com/java/). 


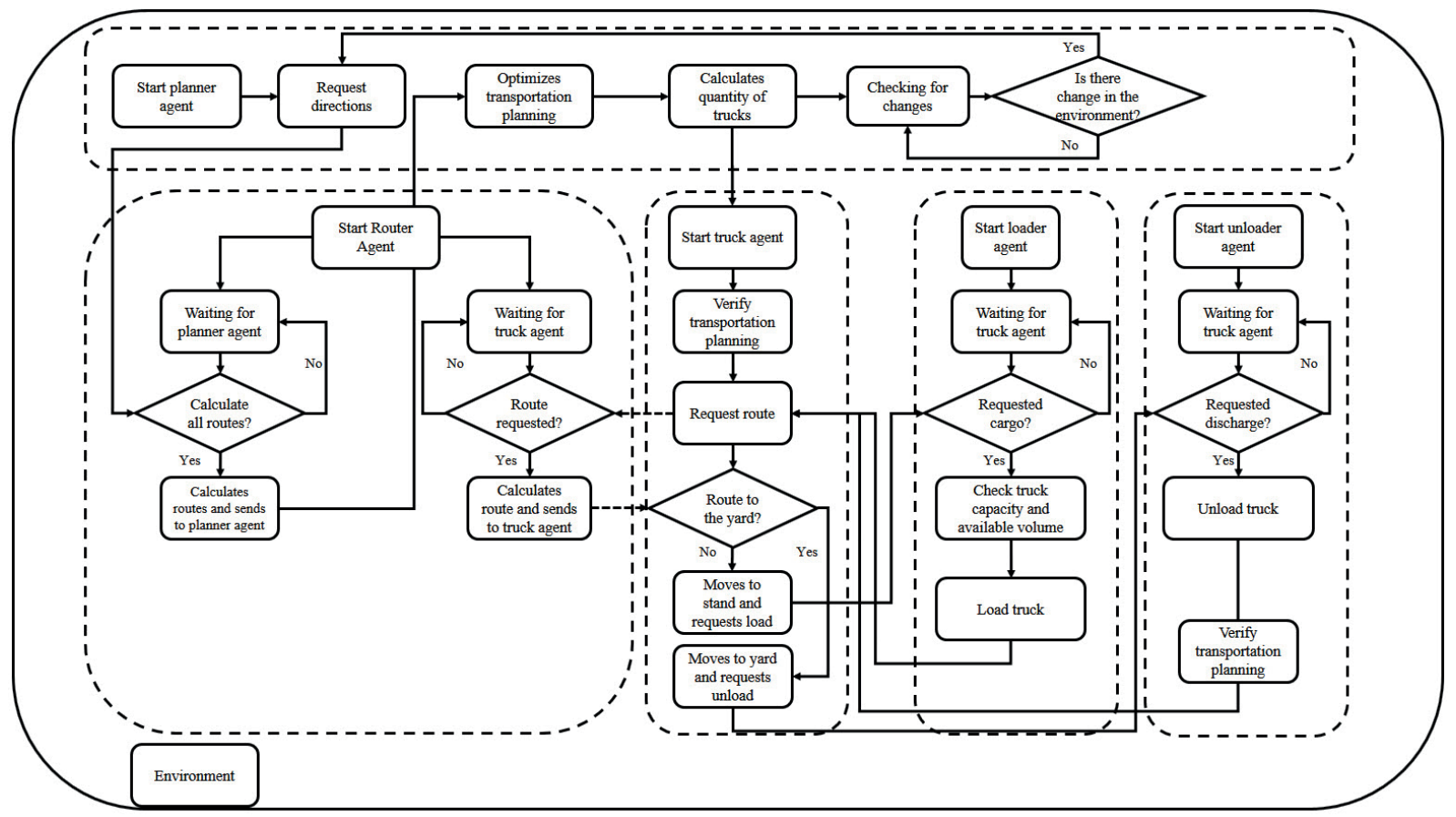

FIGURE I The multi-agent system and the relationship between the agents.

For the multi-agent system to import the map of stands and roads, it was necessary to create a file with the tpk (map tile package) extension and a geodatabase containing a network dataset. These files were built using the ArcGis Software version 10.2.2. The map tile package is used to compress the different layers into a unique file, which is imported by the multi-agent system as the first step in the processing. The network dataset is composed of a set of connected arc, representing the forest roads, with rules of connections and associated attributes as length, cost, time, direction and hierarchies (NICOARA; HAIDU, $20 \mathrm{II}$ ). It is necessary for the functions of route optimization to allow for the identification of the best alternative of wood flux during the forest transportation period.

Aiming for the data used during the processing of the multi-agent system to be all available momentarily, we developed a database management system. For that, we used the Java DB library, which uses the Apache Derby open code database and supports queries in SQL (Structured Query Language) language. It is also important because it allows the data to be recorded in a unique address. The results of the processing of other information from the multi-agent system were inserted in the same database, allowing the use of queries to create graphs and analysis after the processing.

\section{Simulations}

To evaluate the behaviour of the multi-agent system, we performed three simulations. For this, we considered the existence of $32.768 \mathrm{~m}^{3}$, distributed in ten stands, of available wood to be transported, and the system was initiated with the aim of meeting a mill demand, of $40 \mathrm{~m}^{3}$ per hour. The loading rate was 1.4 minutes per cubic metre, and the unloading rate was equal to I.2 minutes per cubic metre of wood volume. The speed, loading rate, unloading rate and vehicle capability were obtained from Machado et al. (2009), and the considered cost was calculated from a mix of data from Alves et al. (20I3) and Machado et al. (2009) (Table I). It was considered only one wood load machine and one wood unload machine.

TABLE I Parameters of the available types of vehicles.

\begin{tabular}{ccccc}
\hline $\begin{array}{c}\text { Truck } \\
\text { Type }\end{array}$ & $\begin{array}{c}\text { Load capacity } \\
\left(\mathrm{m}^{3}\right)\end{array}$ & $\begin{array}{c}\text { Speed } \\
(\text { loaded }) \\
\left(\mathrm{km} \cdot \mathrm{h}^{-1}\right)\end{array}$ & $\begin{array}{c}\text { Speed (empty) } \\
\left(\mathrm{km} \cdot \mathrm{h}^{-1}\right)\end{array}$ & $\begin{array}{c}\text { Cost } \\
\left(\mathrm{R} \$ \cdot \mathrm{m}^{-3} \cdot \mathrm{km}^{-1}\right)\end{array}$ \\
\hline A & 16 & 53 & 64 & 0.36 \\
B & 28 & 46 & 77 & 0.34 \\
C & 90 & 39 & 43 & 0.27 \\
D & 54 & 45 & 53 & 0.29 \\
\hline
\end{tabular}

\section{Optimization of the vehicle fleet}

The system could choose different types of vehicles from Table I in an optimal quantity. After this, we considered that only trucks $A, B$ and $C$ were available to execute the transport operation. The goal was to evaluate if the system was capable of determining the optimal solution to the problem, under different scenarios of truck availability. 


\section{Re-planning of forest transportation considering permanent interruption of routes}

Considering the same data used in Simulations section and assuming that the system works only with truck type $A$, a random permanent interruption was simulated in two parts of the road that are used by the truck fleet for the wood transport. In this case, the goal was to evaluate the multi-agent system capability in rearranging the system structure when an event occurred in the environment.

\section{Re-planning of forest transportation considering temporary interruption of routes}

Considering the same data used in Simulations section, we simulated a random temporary interruption in two parts of the road that are used by the truck fleet for wood transport. The first one had 20 hours of interruption, and the second one had 50 hours. In this case, the objective was to evaluate the multi-agent system capability and rearrange the system structure considering two possibilities: (a) transport from the current stand using a more distant route or (b) changing the location of the source of wood during the period of interruption.

\section{RESULTS}

\section{Optimization of the vehicle fleet}

The optimization of the vehicle fleet indicated the necessity of one truck of type A and two trucks of type $D$ to meet the wood demand from the mill. At end of the multi-agent process, all the wood volume from the stands was transported. It was necessary to take 94I trips to distribute the work among the different trucks, totalling $45,968 \mathrm{~km}$ and a total cost equal to $\mathrm{R} \$ 244,984$.

When the system avoids choosing any quantity of truck type $D$, the fleet was optimized to use one truck of type $A$, one truck of type $B$ and one truck of type $C$. Wood transport took I,022 trips, covered 49,924 km and had a total cost equal to $R \$ 250,276$. The average cost of wood transport was equal to $R \$ 7.55$ per cubic metre, while the value obtained with the first evaluation was equal to $R \$ 7.35$ per cubic metre. Thereby, the use of type $D$ trucks gave transport costs that were $2.8 \%$ more expensive.

\section{Re-planning of forest transportation considering permanent interruption of routes}

At end of the planning process, it was necessary to initially use the four type $A$ trucks to transport the wood from stands to the yard. When the restrictions were inserted at different points in the road network used by the trucks (Figure 2), the multi-agent system automatically recalculated the number of trucks it needed, defining the necessity of one more vehicle.

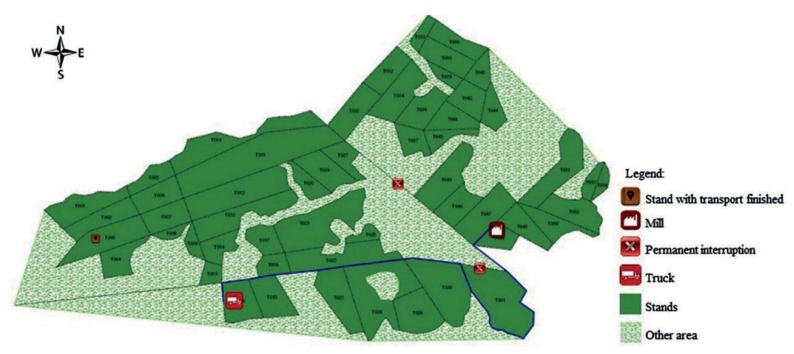

FIGURE 2 Map with indications of permanent interruption of the road, the current stand that has been transported, the location of the yard (mill) and the route that has been used for the transportation (blue line).

Considering the initial condition of the routes (without interruption on track), the average distance was equal to $24.5 \mathrm{~km}$. After insertion of the route restrictions, the average distance was $27.8 \mathrm{~km}$. Because of this, the average cost of transport was changed from $R \$ 8.57$ per cubic metre to $R \$ 9.65$ per cubic metre. The total volume of wood that was transported after 2,053 trips was distributed between the different trucks of the fleet.

The last truck inserted into the multi-agent system transported a smaller volume of wood than others, and this observation indicates that the system was capable of correctly identifying the behaviour of each agent during the process.

\section{Re-planning of forest transportation considering temporary interruption of routes}

The initial optimization of the fleet determined the utilization of I type $A$ truck and 2 type $D$ trucks. When the first interruption was added to the environment, the system determined that the best decision was to change the route without changing the stand where the loading was happening. In this case, the cost of changing the loading location was equal to $R \$ 744.00$, while the cost of using a sub-optimal route was equal to $R \$ 250.00$.

After the insertion of the second interruption, the most economical alternative was to change the load machine to another stand. For this decision, the planner agent compared the moving costs (equals to $\mathrm{R} \$ 792.00$ ) with the cost of transporting the wood using a suboptimal route for 50 hours $(\mathrm{R} \$ \mathrm{I}, 893.00)$. In this case, three stands were blocked to the transport operation according to the result of the binary linear problem during the time of the interruption. 
For that, it was necessary to distribute 82I trips among the different trucks. This value was inferior to the previous simulation, which can be explained by the quantity of trips taken by the trucks with the higher load capacity that occur due to the route interruption.

The average transport distance was changed during the interruption period that was active from 24.5 $\mathrm{km}$ to $25.9 \mathrm{~km}$.

\section{DISCUSSION}

For the first simulation, there was a difference between the quantity of wood transported by the last vehicle in this simulation. This agent had a low acting time in the environment compared to others. It was included only after the road interruption occurred, since its first transport operation corresponded to the $108^{\mathrm{a}}$ step registered in the system.

The planning of forest transport that considers the possibility of the inclusion a permanent restriction in the road network is important for the evaluation of different alternatives that can be adopted by the manager when a problem occurs. One advantage of the multiagent system proposed is the fact that the adoption of these alternatives is supported by the early assessment of the problems, simulating different situations and their impacts on the transport operation.

For instance, if the transport activity is performed by outsourced operations, it is desirable for the service contract to have the possibility of including new trucks without necessarily entering into a new agreement, which would make the process of operation and planning simpler. Another example is the evaluation of the viability in executing the maintenance of forest roads with a higher probability of deterioration and occurrence of interruptions, as well as comparing its value with the possibility of changing the transportation route. These considerations become more important with the increase in pressure by the reduction of costs in a period with economic crises.

For the third case, it is possible to consider that the agents were able to transport all of the wood available at the stands to the yard, since there were two temporary interruptions of the road. An advantage of the use of the computational system as an auxiliary tool for decision support is related to the reduction of the empirical factor. In this case, the manager begins to analyse the problem with a larger quantity of technical and numerical aspects instead of considering only their experience and personal convictions. In fact, Machado et al. (2009) highlight that these technical and quantitative aspects are the most important features against the decision-making and the planning of forest transportation.

Because the multi-agent system was built with detailed considerations about the transport process, it is possible that the manager simulates different configurations and takes practical action in order to improve the logistical system. An example is the evaluation of the load and unload times of the trucks, where the time that the trucks spend waiting for loading or unloading improves the process costs (HARIDASS et al., 20I4).

With a flexible multi-agent system, these analyses are important to support strategies that increase the efficiency of the process and reduce the costs of forest transportation. In agreement with Norstebo et al. (2013), the use of optimization models possibly provides small improvements in efficiency that can reduce costs significantly.

Although recently developed, multi-agent system theory has been used to solve problems in different areas, including in the passenger and goods sector. However, MASs have not been used extensively in forest sector. This work is, therefore, a contribution to help other authors who want to explore this area.

\section{CONCLUSIONS}

The paradigms of multi-agent systems can be applied efficiently to the forest transportation problem, and the developed multi-agent system is flexible enough to maintain the forest transport operation in an optimized way over the working cycle. Thus, the use of dynamic tools allows the forest manager to obtain a set of good conditions to evaluate different possibilities for wood transport planning.

\section{ACKNOWLEDGMENTS}

The authors are grateful to Capes and PróReitoria de Pesquisa da Universidade Federal de Minas Gerais for the financial support.

\section{REFERENCES}

ALVES, R. T.; FIEDLER, N. C.; SILVA, E. N.; LOPES, E. S.; CARMO, F. C. A. Technical analysis and transportation costs of wood with different type of vehicles. Revista Árvore, v. 37, n. 5, p. 897-904, 2013.

BASKENT, E. Z. Combinatorial optimization in forest ecosystem management modelling. Turkish Journal of Agriculture and Forestry, v. 25, n. 3, p. 187-194, 2001.

BELLIFEMINE, F.; CAIRE, G.; GREENWOOD, D. Developing multi-agent systems with JADE. John Wiley and Sons, Chicherster, 2007, 286p. 
BERGER, R.; TIMOFEICZYK, J. R. R.; CARNIERI, C.; LACOWICZ, P. G.; JUNIOR J. S.; BRASIL, A. A. Forestry transportation costs minimization using linear programming. Revista Floresta, v. 33, n. I, p. 53-62, 2003.

CHEN, B.; CHENG, H. H. A review of the applications of agent technology in traffic and transportation systems. IEEE Transactions on Intelligent Transportation Systems, v. II, n. 2, p. 485-497, 2002.

DAVIDSSON, P.; WERNSTEDT, F. A multi-agent system architecture for coordination of just-in-time production and distribution. The Knowledge Engineering Review, v. 17, n. 4, p. 317-329, 2002.

DOMÍNGUEZ, R.; FRAMINAN, J. M. A decision management tool: modelling the order fulfilment process by multi-agent systems. International Journal of Management and Decision Making, v. I2, n. 3, p. 240-258, 2013.

DONIEC, A.; MANDIAU, R.; PIECHOWIAK, S.; ESPIE, S. A behavioral multi-agent model for road traffic simulation. Engineering Applications of Artificial Intelligence, v. 2I, n. 8, p. I443-I454, 2008.

FLISBERG, P.; LIDEN, B.; RONNQVIST, M. A hybrid method based on linear programming and tabu search for routing of logging trucks. Computers \& Operations Research, v. 36, n. 4, p. II22-II44, 2009.

FRISK, M.; GOTHE-LUNDGREN, M.; JORNSTEN, K.; RONNQVIST, M. Cost allocation in collaborative forest transportation. European Journal of Operational Research, v. 205, n. 2, p. 448-452, 2010.

HARIDASS, K.; VALENZUELA, J.; YUCEKAYA, A. D.; MCDONALD, T. Scheduling a log transport system using simulated annealing. Information Sciences, v. 264, n. I, p. 302-316, 2014.

JIFENG, W.; HUAPU, L.; HU, P. System Dynamics Model of Urban Transportation System and Its Application. Journal of Transportation Systems Engineering and Information Technology, v. 8, n. 3, p. 83-89, 2008.

KOHOUT, R.; EROL, K. (1999). In-time agent-based vehicle routing with a stochastic improvement heuristic. In: Eleventh Conference on Innovative Applications of Artificial Intelligence, Orlando, FL, p. I-6.

KONAR, A. Artificial intelligence and soft computing: behavioral and cognitive modeling of the human brain. CRC Press, Boca Raton, 2000, 788p.

LEITÃO, P.; BARBOSA, J.; TRENTESAUX, D. Bio-inspired multi-agent systems for reconfigurable manufacturing systems. Engineering Applications of Artificial Intelligence, v. 25, n. 5, p. 934-944, 2012.
LIN, P.; CONTRERAS, M. A.; DAI, R.; ZHANG, J. A multilevel ACO approach for solving forest transportation planning problems with environmental constraints. Swarm and Evolutionary Computation, v. 28, n. I, p. 78-87, 2016.

LOPES, E. S.; MACHADO, C. C.; SOUZA, A. P.; RIBEIRO, C. A. A. S. Harvesting and wood transport planning with SNAP III program (Scheduling and Network Analysis Program) in a Pine plantation in southeast Brazil. Revista Árvore, v. 27, n. 6, p. 83I-836, 2003.

MACHADO, C. C.; MACHADO, R. R.; SILVA, E. A.; \& SOUZA, M. F. G. Evaluation of the wood hauling logistic performance in farm forest areas using Petri net. Revista Árvore, v. 33, n. 6, p. II59-II67, 2009.

MACHADO, R. R.; SILVA, M. L.; MACHADO, C. C.; LEITE, $H$. G. Evaluation of logistic performance of wood hauling using Petri net in a forest industry of Minas Gerais. Revista Árvore, v. 30, n. 6, p. 999-1008, 2006.

NICOARA, M. E.; HAIDU, I. Creation of the roads network as a network dataset within a geodatabase. Geographia Technica, v. 6, n. 2, p. 8I-86, 20 II.

NORSTEBO, V. S.; JOHANSE, U. Optimal transportation of logs and location of quay facilities in coastal regions of Norway. Forest Police and Economics, v. 26, n. I, p. $7|-8|, 20 \mid 3$.

RENTIZELAS, A. A.; TOLIS, A. J.; TATSIOPOULOS, I. P. Logistics issues of biomass: The storage problem and the multi-biomass supply chain. Renewable and Sustainable Energy Reviews, v. I3, n. 4, p. 887-894, 2009.

RIX, G.; ROUSSEAU, L. M.; PESANT, G. A column generation algorithm for tactical timber transportation planning. Journal of the Operational Research Society, v. 66, n. 2, p. 278-287, 2014.

SILVA, M. L.; OLIVEIRA, R. J.; VALVERDE, S. R.; MACHADO, C. C.; PIRES, V. A. V. Cost and distance of reforestation wood transport for different types of trucks. Revista Árvore, v. 31, n. 6, p. 1073-1079, 2007.

TRONCOSO, J. J.; GARRIDO, R. A. Forestry production and logistics planning: an analysis using mixed-integer programming. Forest Policy and Economics, v. 7, n. 4, p. 605-633, 2005.

WOOLDRIDGE, M. An Introduction to Multiagent Systems. John Wiley \& Sons, Chichester, 2002, 348p. 
